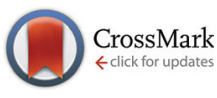

Cite this: Dalton Trans., 2016, 45, 1345

Received 8th December 2015, Accepted 21st December 2015

DOI: $10.1039 / c 5 d t 04796 j$

www.rsc.org/dalton

\section{Cobaltoceniumethynyl gold $(I)$ as an unusual heterodinuclear bioorganometallic fragment to study the biological properties of alkynyl gold complexes $\uparrow$}

\author{
S. Vanicek, ${ }^{a}$ H. Kopacka, ${ }^{a}$ K. Wurst, ${ }^{\text {a }}$ S. Vergeiner, ${ }^{\text {b }}$ S. Kankowski, ${ }^{\mathrm{C}}{ }^{\mathrm{J}}$. Schur, ${ }^{\mathrm{C}}$ \\ B. Bildstein ${ }^{\star a}$ and I. Ott*c
}

\begin{abstract}
A cobaltoceniumethynyl gold(I) complex with a triphenylphosphane ligand triggered efficient cytotoxic effects in cancer cells in contrast to a derivative with two cobaltocenium moieties. The complex effectively inhibited the enzyme thioredoxin reductase (TrxR) suggesting this enzyme as a possible biological target. The cellular uptake of both metal fragments of the active complex was studied by atomic absorption spectroscopy and indicated a high biological stability of the complex.
\end{abstract}

\section{Introduction}

Organometallic gold complexes have recently attracted increasing attention in inorganic medicinal chemistry based on their higher chemical bond stabilities compared to the traditional gold metallodrugs (e.g. auranofin) as well as their sophisticated biological effects. ${ }^{1-3}$ Among these new metal based drugs gold(I) complexes with alkynyl ligands have entered the area of bioorganometallic chemistry and the derivatives that have been studied biologically can be grouped into the following types: neutral mononuclear alkynyl-Au(I)(phosphane), ${ }^{4-8}$ neutral bi/trinuclear (alkynyl-Au(I) $)_{2}$ (alkyldiphosphane) ${ }^{9}$ and di/trialkynyl-(Au(I)(phosphane) $)_{2 / 3}, 8,10$ and anionic mononuclear (alkynyl) ${ }_{2} \mathrm{Au}(\mathrm{I})^{5}$ complexes. As a general note, the biological activities depended on the type of alkynyl and

\footnotetext{
${ }^{a}$ Institute of General, Inorganic and Theoretical Chemistry, University of Innsbruck, Center for Chemistry and Biomedicine, Innrain 80-82, A-6020 Innsbruck, Austria. E-mail:Benno.Bildstein@uibk.ac.at

${ }^{b}$ Institute of Organic Chemistry, University of Innsbruck, Center for Chemistry and Biomedicine, Innrain 80-82, A-6020 Innsbruck, Austria

${ }^{c}$ Institute of Medicinal and Pharmaceutical Chemistry, Technische Universität Braunschweig, Beethovenstr. 55, 38106 Braunschweig, Germany.

E-mail: ingo.ott@tu-bs.de

$\dagger$ Electronic supplementary information (ESI) available: More details of crystallography, Experimental section, videos of time-lapse microscopy. CCDC 1436182 and 1436183. For ESI and crystallographic data in CIF or other electronic format see DOI: $10.1039 / \mathrm{c} 5 \mathrm{dt} 04796 \mathrm{j}$
}

phosphane ligand and bioavailability was found to have a strong impact on the outcome of the biological studies.

In order to extend the pool of investigated types and to address the issue of bioavailability new alkynylgold(I) model complexes were designed, which feature a positive charge and a second metal moiety (cobaltocenium) as differences to the above listed types. In particular the cationic and heteronuclear character appeared promising considering bioavailability, reported pharmacological effects of different heterobimetallic gold organometallics, ${ }^{11-14}$ and the option to monitor cellular accumulation of different metal fragments of an individual compound. Additionally, the non cytotoxicity, high stability and bioavailability of the cobaltocenium moiety made this organometallic a perfect choice for the here described study. ${ }^{15-17}$

\section{Chemistry}

As we have recently reported, trimethylsilylethynylcobaltocenium hexafluorophosphate (1) is available in $86 \%$ yield from cobaltocenium hexafluorophosphate by a two step protocol involving nucleophilic addition of trimethylsilylacetylide followed by oxidation/hydride removal with tritylium hexafluorophosphate. ${ }^{18}$ Removal of the trimethylsilyl protecting group is easily possible with sodium fluoride, affording ethynylcobaltocenium hexafluorophosphate in $75 \%$ overall yield. ${ }^{18}$ Having these starting materials in hand, gold(I) complexes 2 and 3 were prepared as outlined in Scheme 1. At first one might think that a standard organometallic approach involving deprotonation of ethynylcobaltocenium hexafluorophosphate would be the obvious route to the free ligand, and simple transmetalation with suitable gold electrophiles would give easy access to the desired cobaltoceniumethynide metal complexes. However, in practice this is not the case. Attempted formation of cobaltoceniumethynide by reaction of ethynylcobaltocenium hexafluorophosphate with butyl lithium in dry tetrahydrofuran showed that the betaine cobaltoceniumethynide is unstable, it reacted further by intermolecular nucleophilic exo-addition to the cobaltocenium moiety. This is a 


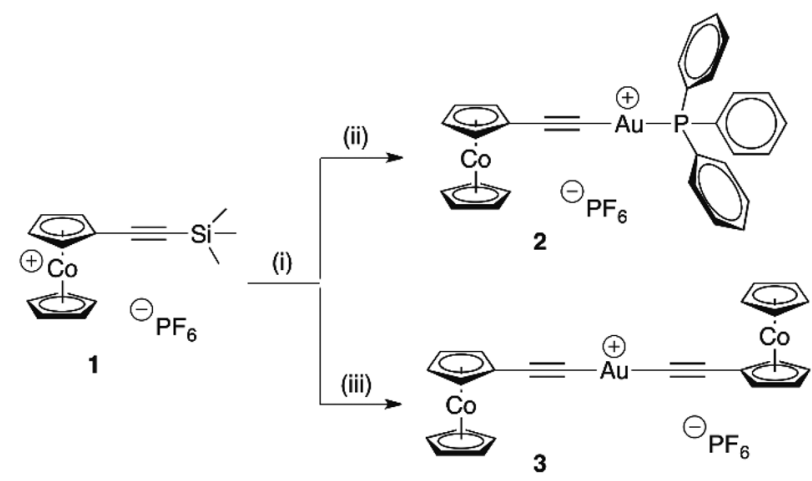

Scheme 1 Synthesis of gold(I) cobaltoceniumethynide complexes 2 and 3. Reaction conditions: (i) $\mathrm{NaF} / \mathrm{H}_{2} \mathrm{O} / \mathrm{CH}_{3} \mathrm{CN}$, (ii) $\left[\left(\mathrm{H}_{5} \mathrm{C}_{6}\right)_{3} \mathrm{P}\right] \mathrm{AuCl}$, (iii) $\left[\left(\mathrm{H}_{3} \mathrm{C}\right)_{2} \mathrm{~S}\right] \mathrm{AuCl}$.

general reaction of carbanions with cobaltocenium salts, ${ }^{19}$ in our case (unseparable) mixtures of various endohydride species were observed.

Therefore, we used trimethylsilylethynylcobaltocenium hexafluorophosphate (1) as starting material that allowed in situ formation of the free betaine ligand cobaltoceniumethynide with concomitant complex formation by deprotection with sodium fluoride in the presence of gold precursor complexes chloro(triphenylposphane)gold(I) and chloro(dimethylsulfide)gold(I), respectively. Under these convenient reaction conditions - aqueous solution, no inert atmosphere necessary - gold cobaltoceniumethynide complexes 2 and 3 were obtained as yellow powders in $45 \%$ and $63 \%$ yield, respectively. Both compounds contain the cobaltoceniumethynide ligand, an acceptor-substituted unusual "neutral" alkynide betaine due to its cationic cobaltocenium part. These two compounds are new examples of rare cationic $\mathrm{Au}(\mathrm{I})$ alkynide complexes, to the best of our knowledge the only other representative is $[$ di(N-methylpyridinium-4-ethynide)gold(I) $]$ iodide. ${ }^{20}$

Electronically, a regular 18 valence-electron cobaltocenium moiety with a d $\mathrm{d}^{6}$-Co(III) metal center is present, therefore 2 and 3 are diamagnetic compounds that are amenable to NMR characterization.

Most significant, the ${ }^{13} \mathrm{C}$-signals of the ethynyl carbons are observed for complex 2 at $90.3 \mathrm{ppm}(\mathrm{Au}-\mathrm{C} \equiv \mathrm{C})$ and $129.2 \mathrm{ppm}$ $(\mathrm{Au}-\mathrm{C} \equiv \mathrm{C})$, or for complex 3 at $93.4 \mathrm{ppm}(\mathrm{Au}-\mathrm{C} \equiv \mathrm{C})$ and $147.8 \mathrm{ppm}(\mathrm{Au}-\mathrm{C} \equiv \mathrm{C})$, respectively. The ethynyl group is also evident by its stretching vibration in the IR spectra: $\nu_{(\mathrm{C} \equiv \mathrm{C})}=$ $2108 \mathrm{~cm}^{-1}$ (2), $2099 \mathrm{~cm}^{-1}$ (3).

Further spectroscopic characterization is provided by observation of the molecular ions of the cations of 2 and 3 in the positive mode FAB-mass spectra (compare Experimental section). For both complexes single crystal structure analyses are available (Fig. 1 and ESI $\dagger$ ). +

\section{Biological evaluation}

As a first step in the characterisation of their biological properties, the cell growth inhibition of complexes 2 and 3 was

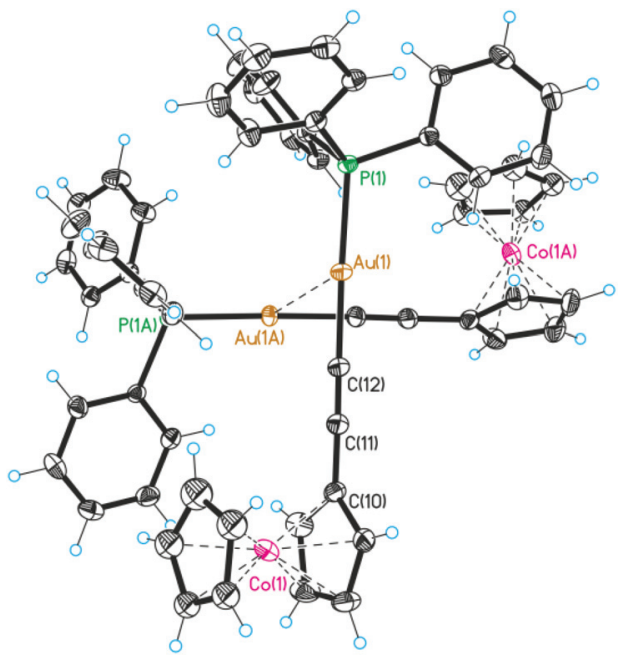

Fig. 1 Molecular structure of the cation of 2 showing thermal ellipsoids at $20 \%$ probability. Hexafluorophosphate counterions are ommitted for clarity.

determined in two cancer cell lines (HT-29 colon carcinoma and MDA-MB-231 breast cancer) as well as a non tumor cell line (RC-124 human kidney) (Table 1).

The monoalkynyl gold complex 2 triggered strong cytotoxic effects $\left(\mathrm{IC}_{50}\right.$ values in the range of $\left.4-14 \mu \mathrm{M}\right)$ in all cell lines and these data are in good agreement with previous studies on alkynylgold(I)(phosphane) complexes. ${ }^{4,5,9}$ However, 2 was not selective for tumor cells as its activity in RC-124 cells was similar. In contrast to this, the dialkynyl derivative 3 was inactive against HT-29 and MDA-MB-231 cells and showed some minor effects against RC-124 cells. The cytotoxicity against RC-124 has also been observed with other metal complexes in our ongoing studies and might at least be in part related to different growth and cell culture conditions (e.g. RC-124 are maintained in gelatine pretreated cell culture flasks in contrast to the more robust and more adherent HT-29 and MDA-MB-231 cells). In this context it should also be noted that the cobaltocenium fragment itself is a non toxic moiety, and therefore the observed cell growth inhibitory activities can be ascribed to the gold(I) containing partial structure. ${ }^{15}$

Microscopic evaluation of the effects of 2 against MDA-MB-231 cells showed a significant reduction of the cell layer, strong morphological changes and rounding up with detachment of the surface (Fig. 2). This further confirms the strong cytotoxic effects of the compound and indicates the induction of apoptotic processes leading to cell death. Time-

Table 1 Antiproliferative effects ( $\mathrm{IC}_{50}$ values) of complexes 2 and 3

\begin{tabular}{lrl}
\hline & \multicolumn{1}{l}{2} & 3 \\
\hline HT-29 & $13.8 \pm 1.4 \mu \mathrm{M}$ & $>100 \mu \mathrm{M}$ \\
MDA-MB-231 & $5.0 \pm 0.5 \mu \mathrm{M}$ & $>100 \mu \mathrm{M}$ \\
RC-124 & $4.4 \pm 1.2 \mu \mathrm{M}$ & $31.6 \pm 3.9 \mu \mathrm{M}$
\end{tabular}




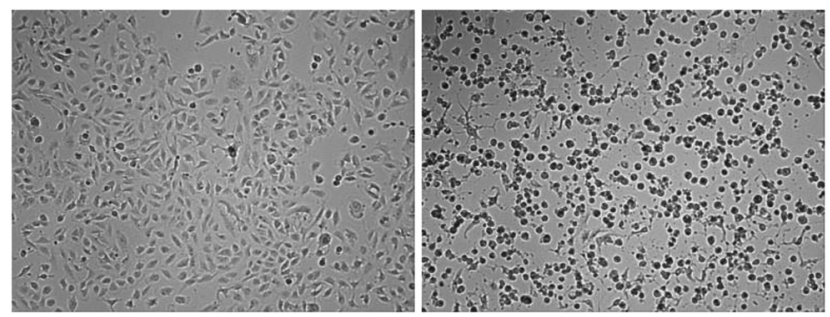

Fig. 2 Morphological changes in MDA-MB-231 cells exposed to $5 \mu \mathrm{M}$ of 2; left: start of the exposure $(0 \mathrm{~h})$, right: $72 \mathrm{~h}$.

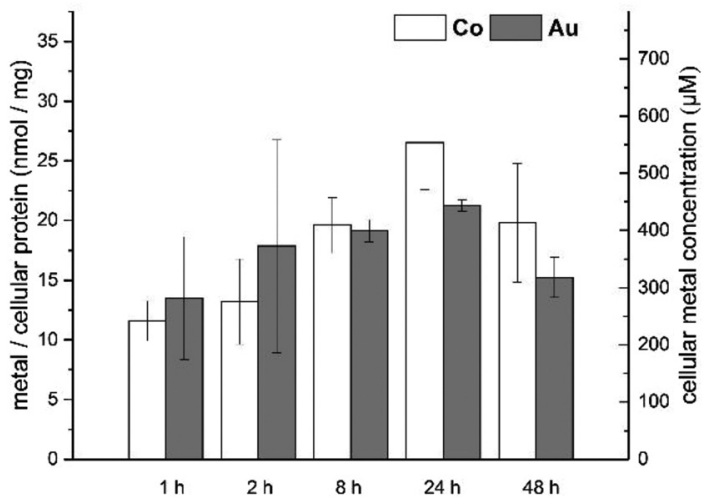

Fig. 3 Cellular gold and cobalt levels of HT-29 cells exposed to $20.0 \mu \mathrm{M}$ of complex 2 .

lapse microscopy showed that the cytotoxic effects occurred already after short exposure within a few hours and continued over the whole exposure period (see video in the ESI $\dagger$ ).

The enzyme thioredoxin reductase is considered as an important molecular target for many gold species. ${ }^{1-3}$ In fact complex 2 was an effective inhibitor of TrxR with an $\mathrm{IC}_{50}$ value of $0.110( \pm 0.007) \mu \mathrm{M}$.

As indicated above, the combination of a cobaltocenium moiety and gold(I) in a single organometallic compound suggests to monitor the bioavailability of both metals simultaneously. Comparable levels of both metals in biological tissue would indicate that the compound is transported in an intact form. High resolution continuum source atomic absorption spectroscopy was used to assess both gold and cobalt levels in cells exposed to the bioactive complex 2 over a period of $48 \mathrm{~h}$ according to previously established procedures (Fig. 3). ${ }^{21,22}$ The HT-29 cell line was chosen for this purpose as 2 triggered a higher $\mathrm{IC}_{50}$ value in this cell line allowing exposure to higher concentration of the compound without strong reduction of the cell biomass. To the best of our knowledge, this is the first report on the quantification of cellular uptake of both transition metals of a heterodinuclear complex by an appropriate trace element spectrometric technique.

In fact over the whole exposure period the levels of cobalt and gold were in a comparable range within the experimental errors of the assay (range: 10-30 nmol of metal per milligram of cell protein). This indirectly suggests that the complex enters the cells in an intact form without major dissociation of the two organometallic fragments.

The measured cellular metal levels in HT-29 cells corresponded to molar cellular concentrations roughly in the range of 200-600 $\mu \mathrm{M}$.§ Taking the exposure concentration of $20 \mu \mathrm{M}$ into account, this shows that $\mathbf{3}$ is effectively accumulated in the cells approximately 10-30-fold. The cellular metal levels were achieved rapidly (high levels already after $1 \mathrm{~h}$ of exposure) and were stable with only a not significant decrease after extended incubation $(48 \mathrm{~h})$.

\section{Conclusions}

In conclusion we reported here on an unusual heterobimetallic gold alkynyl complex with a cobaltocenium partial structure. The bimetallic character of the compound allowed simultaneous monitoring of the cellular uptake of both metal moieties and indirectly suggested a high biological stability of the compound. The complex is a strong inhibitor of TrxR, which is a common biological target for many gold species.

\section{Notes and references}

$\ddagger$ CCDC 1436182 (2) and 1436183 (3) contain the supplementary crystallographic data for this paper.

$\S$ Cellular uptake is expressed as amount of metal per mass of cellular protein (determined by the Bradford method). Knowledge of certain cell parameters, such as diameter and cell protein content, allows to calculate molar concentrations. See ref. 22 and 23 for details.

1 I. Ott, Coord. Chem. Rev., 2009, 253, 1670-1681.

2 B. Bertrand and A. Casini, Dalton Trans., 2014, 43, 42094219.

3 T. Zou, C. T. Lum, C.-N. Lok, J.-J. Zhang and C.-M. Che, Chem. Soc. Rev., 2015, 44, 8786-8801.

4 A. Meyer, C. P. Bagowski, M. Kokoschka, M. Stefanopoulou, H. Alborzinioa, S. Can, D. H. Vlecken, W. S. Sheldrick, S. Wölfl and I. Ott, Angew. Chem., Int. Ed., 2012, 51, 88958899.

5 J. Arcau, V. Andermark, E. Aguilo, A. Gandioso, A. Moro, M. Cetina, J. C. Lima, K. Rissanen, I. Ott and L. Rodriguez, Dalton Trans., 2014, 43, 4426-4436.

6 E. E. Langdon-Jones, D. Lloyd, A. J. Hayes, S. D. Wainwright, H. J. Mottram, S. J. Coles, P. N. Horton and S. J. A. Pope, Inorg. Chem., 2015, 54, 6606-6615.

7 E. Schuh, S. M. Valiahdi, M. A. Jakupec, B. K. Keppler, P. Chiba and F. Mohr, Dalton Trans., 2009, 10841-10845.

8 E. Vergara, E. Cerrada, A. Casini, O. Zava, M. Laguna and P. J. Dyson, Organometallics, 2010, 29, 2596-2603.

9 A. Meyer, A. Gutiérrez, I. Ott and L. Rodríguez, Inorg. Chim. Acta, 2013, 398, 72-76.

10 C.-H. Chui, R. S.-M. Wong, R. Gambari, G. Y.-M. Cheng, M. C.-W. Yuen, K.-W. Chan, S.-W. Tong, F.-Y. Lau, 
P. B.-S. Lai, K.-H. Lam, C.-L. Ho, C.-W. Kan, K. S.-Y. Leung and W.-Y. Wong, Bioorg. Med. Chem., 2009, 17, 7872-7877.

11 J. Fernandez-Gallardo, B. T. Elie, T. Sadhukha, S. Prabha, M. Sanaú, S. A. Rotenberg, J. W. Ramos and M. Contel, Chem. Sci., 2015, 6, 5269-5283.

12 M. C. Gimeno, H. Goitia, A. Laguna, M. E. Luque, M. D. Villacampa, C. Sepúlveda and M. Meireles, J. Inorg. Biochem., 2011, 105, 1373-1382.

13 M. Frik, J. Fernández-Gallardo, O. Gonzalo, V. MangasSanjuan, M. González-Alvarez, A. Serrano del Valle, C. Hu, I. González-Alvarez, M. Bermejo, I. Marzo and M. Contel, J. Med. Chem., 2015, 58, 5825-5841.

14 L. Massai, J. Fernández-Gallardo, A. Guerri, A. Arcangeli, S. Pillozzi, M. Contel and L. Messori, Dalton Trans., 2015, 44, 11067-11076.

15 S. Vanicek, H. Kopacka, K. Wurst, S. Vergeiner, L. Oehninger, I. Ott and B. Bildstein, Z. Anorg. Allg. Chem., 2015, 641, 1282-1292.
16 F. Noor, A. Wüstholz, R. Kinscherf and N. Metzler-Nolte, Angew. Chem., Int. Ed., 2005, 44, 2429-2432.

17 F. Noor, A. Kinscherf, G. A. Bonaterra, S. Walczak, S. Wölfl and N. Metzler-Nolte, ChemBioChem, 2009, 10, 493-502.

18 S. Vanicek, H. Kopacka, K. Wurst, T. Müller, H. Schottenberger and B. Bildstein, Organometallics, 2014, 33, 1152-1156.

19 J. E. Sheats, Organomet. Chem. Rev., 1979, 7, 461-521.

20 M. Ferrer, L. Rodriguez, O. Rossell, F. Pina, J. C. Lima, M. Font-Bardia and X. J. Solans, J. Organomet. Chem., 2003, 678, 82-89.

21 S. I. Kirin, I. Ott, R. Gust, W. Mier, T. Weyhermüller and N. Metzler-Nolte, Angew. Chem., Int. Ed., 2008, 47, 955-959.

22 I. Ott, H. Scheffler and R. Gust, ChemMedChem, 2007, 2, 702-707.

23 R. Gust, B. Schnurr, R. Krauser, G. Bernhardt, M. Koch, B. Schmid, E. Hummel and H. Schönenberger, J. Cancer Res. Clin. Oncol., 1998, 124, 585-597. 